\title{
On-farm Soybean Seed Production Through Initiating and Supporting Seed and Grain Producer Farmer Groups in Southwest Ethiopia
}

\author{
Masreshaw Yirga $^{1} \quad$ Yechalew Sileshi $^{1} \quad$ Mesfin hailemariam $^{2} \quad$ Behailu Atero $^{1}$ \\ ${ }^{1}$ Ethiopian Institutes of Agricultural Research, Jimma Agricultural Research, Department of Field crop division \\ ${ }^{2}$ Ethiopian Institutes of Agricultural Research, Wolkitie Agricultural Research, Department of Field crop \\ division
}

\begin{abstract}
Improved seed is among the most key input for increasing soybean production and productivity by significant folds, at the end ensuring food security and improving livelihoods in the country. Facilitating and accessing quality seed to small holder farmers require proper understanding of seed systems. Soybean production and productivity particularly in southwestern Ethiopia is constrained by inadequate availability of good quality seeds, lack of proper market channels, and market information. This study is therefore conducted to solve seed production and distribution problem in south west Ethiopia viz 4 selected weredas of Jimma, Buno Bedele and Illuababore zones, which aimed at enhancing soybean variety seed production technology and disseminating through establishing and supporting small scale seed producer farmers. The research approach consisted of stakeholder's platform meeting, establishment of soybean seed producer farmer groups, technical skills and capacity building. The research finding revealed that Stakeholders' platform was organized and arranged to discuss and share ideas/ responsibilities. A validation platform was organized with 154 participants from ministry of agriculture(MOA),Jimma agricultural research center(JARC), jimma University, cooperatives/unions, private enterprises, model farmers, then soybean seed producer farmers groups were created, which consisted of 20-30 farmers with a land holding of 0.125-0.25 hectare. Accordingly, JARC has given 22 quintals of soybean foundation seed and Biofertilizer to seed producer farmers group. Training on improved soybean seed production and soybean food recipe was given to farmers, MOA and Cooperative office experts, researchers, development agents and other officers. At the beginning, JARC was disseminating initial improved seed for small scale farmers, but, now a days; ministry of agriculture, cooperative and unions took responsibility of supporting and supplying seed, to alleviate market access, they have been later purchasing the seed from farmers. This linkage is just due to the impact of common understanding and awareness created through stakeholder platform and training. In this research, 200 seed producer farmers were participated in the system, as result more than 300 quintal soybean seed was produced and disseminated to small scale farmer and a total of 70 hectare was covered by soybean seed during research phase.
\end{abstract}

Keywords: improved seed, seed system, soybean, small scale farmers

DOI: $10.7176 / J N S R / 11-15-03$

Publication date:August $31^{\text {st }} 2020$

\section{Introduction}

Soybean (Glycine max (L.) has been one of the most important source of vegetable oil crop in worlds economy. The crop is also the chief Source of dietary protein (40\%), vitamins and essential minerals for small holder farmers, particularly for the most vulnerable subsets of impoverished families such as women and children. In addition, it plays a critically role in soil fertility improvement through fixing biological nitrogen. Despite the enormous importance of soybean, its productivity receives only a fraction of the formal investments or almost neglected in compared with investments in other cereal crops in Ethiopia.

As agriculture is the dominant economic sector in the country, the uses of improved agricultural technologies are very crucial to boost agricultural production and productivity, thereby, ensure food security and reduce poverty. To this end soybean breeding research program in Ethiopia has released twenty six varieties for different agroecologies of the country (MOANR, 2016). Although, the release of several improved varieties, there has been limited use of improved seed by small scale farmers. According to Agricultural Sample Survey of CSA report (2016) the total annual area covered by soybean was 38072.70 hectare and its production was 864,678.69 quintal, which is very low compared to the world average. One of the important reasons is lack of substantial improved seed and poor extension services (MOA, 2013; Kumelachew Alemu, 2015).

Seed is a key input for improving crop production and productivity. Increasing the quality of seed can increase the yield potential of the crop by significant fold and thus, is one of the most economical and efficient input to agricultural development (FAO, 2006). Generation and transfer of improved technology are decisive prerequisites for agricultural development mainly for agricultural based economy for instance Ethiopia. Apart from generation and transfer of improved technology, unavailability of quality seeds at the right time and place coupled with poor promotion system, is one of the key factors accounting for limited use of improved seeds, which further 
contributing for low agricultural productivity (Atilaw, 2010).

Seed system refers to all the processes related to the development, conservation, production, storage and dissemination of varieties (Tripp, 1997). Ethiopian seed system is categorized in to formal and the informal main sectors. Both systems are operating simultaneously in the country and difficult to differentiate between the two. The formal sector is lead by institutional operations which is mandated to produce full packaged improved variety seed and disseminate to farmers (Zewdie et al., 2000). There is a fact that, the formal system is the original source of improved seeds in the informal system. However, the formal seed sector meets only less than $10 \%$ of the total seed demand of our farmers in Ethiopia. The informal seed system is defined as informal seed production and distribution practices with no legal seed certification (Dawit et al., 2010), it is sometimes called local or farmer's seed system. Other forms of seed systems operating in both systems also exist such as Community-Based Seed System (CBSS) (Zewdie et al., 2008). The majority of Ethiopian farmers show a tendency of depending on the informal seed system due to, primarily, it is relatively cheaper and readily available in the farmer's villages simply at the time of seed is required and it allows the use of seeds after testing on primary adopter farmers and it is more reliable and its sustainability is more guaranteed than the formal system (Abebe, 2010).

Southwestern of Ethiopia is potential and favorable environment for soybean commercial production purposes as well as for subsistence farming system. Besides other agronomic production constraints, Soybean production and productivity in this region is constrained by inadequate availability of good quality seeds improved soybean varieties, lack of proper market channels for seeds, and lack of market information. Generally, Soybean seed production and supply of released varieties has been carried out in disorganized, week and inconsistent supplier of improved seeds in Ethiopia. There are only few private seed companies engaged in soybean seed production in the country, but none of these companies supply seeds of improved soybean varieties to farmers in Southwestern Ethiopia. So far, the major suppliers of improved soybean seeds in the region are Jimma, Bako and Assossa Agricultural Research Centers, and CASCAPE project at Jimma University.

Starting from the 1988, Jimma agricultural research center (JARC) has demonstrated and popularized released soybean variety through on-farm demonstration, seed multiplication and distribution, field days, exhibition on soybean recipe and trainings in Jimma, Buno Bedeleand Illubabor zones. To date, JARC has, distributed more than 450 quintal improved soybean variety seed. Trainings soybean production and management was given for more than 6930 farmers. During training, 7720 soybean production leaf lets were distributed for farmers and developmental agent. Moreover, in each cropping year, field day has been prepared for different stakeholders and exhibition on soybean recipe and trainings was also given for 4160 female farmers. Despite the progress made in the development and popularization of improved soybean varieties by the research center, their adoption by farmers still remains low largely because of lack of availability of good quality seed of the released varieties and market access. Due to a huge difference between supply and demand for seed, farmer based seed production is essential (Endeshaw et al 2011). Because, a group or collective action approach has proven to be an effective way to empower farmers in accessing new technologies, particularly seed (Anandajayasekeram et al. 2008). Based on this fact, Jimma agricultural research center (JARC) is doing its best to enhance soybean variety seed production technology and dissemination through establishing and supporting small scale seed producer farmers.

\section{Objectives}

$\checkmark \quad$ To increase soybean production and productivity of soybean in Ethiopia and

$\checkmark$ To enhance skills and knowledge of members of the specialized seed producer farmers groups on production, supply and marketing in southwest Ethiopia.

\section{Material and Methods}

Description of the study area: This activity was conducted at selected wereda of Jimma, Buno Bedele and Illubabor zones of Southwest Ethiopia during 2017-2019 cropping seasons. These three zones have been the major soybean scaling up target zones of Jimma Agricultural Research Center (JARC). Consequently, wider awareness on the importance of soybean and the use of best soybean production practices to improve production and productivity has been created, which has led to increased demand for good quality seed of the released varieties. Based on previous efforts made to scale up soybean production and the current awareness and status of soybean production, two weredas in Jimma zones ( Serbo and Tiroafeta), one wereda in Buno Bedle zone (Bedele Woreda) and two weredas in Illubabor zones (Chewaka and Darimu) were selected to establish and strengthen the seed producer groups. One seed producer group from each of the selected weredas was established and strengthened. The work was implemented with integration of different stockholders from JARC soybean breeders, socioeconomist and agricultural extensionist, zonal and Wereda Ministry of agriculture (MOA), unions and cooperatives. Prior to executing the field research, Preliminary surveying and exploration of the benefits of improved soybean technology was done. A variety of factors such as accessibility and feasibility of the experiment were considered. 
Role/Responsibilities of partners: The linkage and sharing of responsibilities among the stakeholders, which were engaged in developing local seed system is important to improve seed system and production in rural communities. Accordingly, partners were shared the following roles/responsibilities (Table 1).

Table 1: Roles and responsibilities of partners in establishing soybean seed producers /farmers group in each zone.

\begin{tabular}{|c|c|}
\hline Stakeholders & Roles/Responsibilities \\
\hline $\begin{array}{r}\text { Agricultural } \\
\text { Center }\end{array}$ & $\begin{array}{l}\text { - Production and supply of breeder/foundation seed. } \\
\text { - Provision of information on the varieties } \\
\text { - Support other partner skills and knowledge enhancement } \\
\text { - Facilitate linkages with partners } \\
\text { - Organize training on seed production and multiplication techniques. } \\
\text { - Establishment of seed producer /farmers groups in collaboration with other } \\
\text { - } \text { partner. }\end{array}$ \\
\hline $\begin{array}{l}\text { Wereda agricultural } \\
\text { development offices }\end{array}$ & $\begin{array}{l}\text { - Support and Provide extension services in seed production, distribution and } \\
\text { marketing } \\
\text { - Periodic follow up and inspection of each seeds multiplication field. } \\
\text { - Support in linking seed production with market/buyers }\end{array}$ \\
\hline $\begin{array}{l}\text { Seed producer farmers } \\
\text { groups }\end{array}$ & $\begin{array}{l}\text { - Production and supply of improved soybean seed } \\
\text { - Dissemination of seed and information to smallholder farmers } \\
\text { - Test the variety supported by extension service providers and suggest feedback to } \\
\text { the research center. }\end{array}$ \\
\hline cooperatives /Union & $\begin{array}{l}\text { - Provision of agricultural input such as fertilizer, seed, chemicals to farmers on } \\
\text { loan or cash } \\
\text { - Provide storage services to soybean seed producers and market information to } \\
\text { farmers (their members). } \\
\text { - Facilitate acquisition of foundation seed and other technologies from the research } \\
\text { center. }\end{array}$ \\
\hline
\end{tabular}

\section{Research finding and Discussion}

Plat form meeting and establishment of seed producer farmers groups

In the establishment of soybean seeds producer groups and in disseminating of the seeds, strong stakeholder linkage among stakeholders plays a great role in achieving the objectives of the study. Stakeholders' platform was organized and arranged to discuss and share ideas/ responsibilities. A validation platform was organized with 154 participants, including ministry of agriculture (77), Jimma agricultural research center(33), Jimma University CASCAPE project (3), Bureau of cooperatives/unions(31), private enterprises working on soybean business(2),model farmers(8). The participants were invited on the basis of the involvement of their organization in soybean value chains in general, and in soybean seed systems in particular. during this consultative meeting , the results obtained from the various discussions such as stakeholders and their role in the informal soybean seed systems were presented and actors provided further inputs regarding the farmers seed producer group and functioning of soybean seed systems in Ethiopia. Organizational arrangements for soybean seed production and marketing were proposed by stakeholders and thoroughly discussed.

Since, the limited soybean seeds production and supply in the selected weredas, to improve the seed supply and production, one seed producer farmers group from existing cooperative was selected from each wereda. JARC was conducted the selection in collaboration with agricultural development offices and cooperatives/unions. Each seed producer farmers groups were created which consisted of 20-30 farmers with a land holding of 0.125-0.25 hectare. Farmers in each group were selected based on technical capabilities, interest and the land to be allocated for seed multiplication. The soybean seed producer farmers were selected from purposively selected existing marketing cooperatives. The cooperatives war selected based on their previous experience in soybean production. Therefore, 200 seed producer farmers were participated in the system.

Seed variety selection and input facilitation: improved soybean variety seed was selected based on yield potential, resistance to tolerance to disease, adaptable, availability and seed quality. This was accomplished with the expert's consultation of breeders from JARC. Therefore the selected variety were Clark 63K, Nyala and Afgat), which are the most popular, adaptable variety and attractive yellow seed coat color, in southwest Ethiopia. Hence initial seed of this variety was given to soybean seed growers. Moreover, fertilizer and other important packages were avail for the growers in partner with zonal and wereda actors. Accordingly, 22 quintals of soybean foundation seed and rhizobia Biofertilizer was given to the above mentioned five wereda.

Technical skills and capacity building: The first most important step in the seed production activity is creation of awareness as well as potential demand for particular varieties. Creating awareness on improved varieties best 
agronomic practices, and using quality seed for production are key aspects to help farmers understand the basic principles of good quality seed production and marketing. Therefore, technical skill and capacity building through training, demonstration, and farmers field days for soybean seed producer gruops, development agents and bureau of agriculture experts, have paramount significance in ensuring accessibility of good quality seed of improved varieties. Such trainings were provided by researchers of different disciplines from JARC. Technical support for seed producer groups from research and extension services is also essential in early stages of producer group's formation. Moreover, skills and knowledge in seed storage, seed quality management, marketing and supply enhances uptake and spread of improved seeds and practices, and keeps -smallholder seed enterprise commercially viable.

The trainings were provided to each member of the seeds producer groups in three phases. First training was conducted before sowing, second at active growing stage and third at the time of maturity and harvesting. The training includes general seed production techniques, quality seed production, agronomic practices, crop protection, the use of improved varieties and post-harvest handling. Hence training on improved soybean seed production and quality soybean seed production was organized and given to 343 participants, including farmers(274), MOA and Cooperative office experts (18), researchers(5), development agents(36) and other officers 10). The training was given by an agronomist and breeders. For the above two training session's short notes were given to development agents and wereda experts. More over seed production guidelines, manuals and leaflets were distributed to each of the trainees.

Farmers' field day was organized by JARC in collaboration with partners to increase awareness among all stakeholders on the improved soybean seeds available in their area and to validate and disseminate the varieties to all the kebeles in the woredas.

Field supervision was executed in each research year. Generally, at the beginning, JARC was disseminating initial improved seed for small scale farmers, but now a days; ministry of agriculture, cooperative and union took responsibility of supplying seed. To overcome the problem of market access, they have been later purchasing the seed from farmers. This linkage is just due to the impact of common understanding and awareness created through stakeholder platform and training. In this research, more than 300 quintal soybean seed was disseminated to small scale farmer groups, and a total of 70 hectare was covered by soybean, with the land holding of $0.125-0.25$ hectare per each selected small scale farmer.

\section{Conclusion and recommendation}

Soybean is the most important oil crop in both area coverage and volume of annual production in Ethiopia. The productivity of oil in general and soybean in particular in Ethiopia is still, far below its potential due to lack of improved seed and lack of attention by the government. Seed is one amongst the foremost necessary sources of innovation, notably in resource-constrained small farm environments. However, the use of improved seed remains very low in the country. In Ethiopia two main seed sectors have been recognized; the formal and informal. Other forms of seed systems operating in both systems also exist such as Community-Based Seed System. Though the legal seed sector was responsible for the production of seed for all crops, their seed production is dominated by a few cereal crops, mainly hybrid maize and wheat. Therefore the informal seed sector remains the source of seed for the farming community. A successful seed program that supplies a sufficient quantity of high quality seed of adapted varieties on time and with reasonable cost remains to be a major constraint. As a result, the seed supply of soybean production mostly dependent on the informal seed system supplied through community based seed production as well as demonstration and popularization activities conducted by research institutes and other stakeholders. To sum up, although, soybean play tremendous role in addressing future global food and nutritional security problem, adoption and expansion of this crop is generally limited in Ethiopia. This is due to weak agricultural extension, lack availability of improved seed to small scale farmers and less attention given by the government. Hence in order to more scale up this important crop through accessing improved seed, due attention should be given to have tough agricultural extension and advisory services, appropriate policies, and strong institutional arrangements which will facilitate improvement of this crop technology.

\section{Reference}

Abebe, A. (2010). A baseline survey on the Ethiopian seed sector.Submitted to the African seed trade association. Addis Ababa, Ethiopia.

Anandajayasekeram P., Puskur R., Workneh S. and Hoekstra D. 2008. Concepts and practices in agricultural extension in developing countries. A source book. Washington, DC: IFPRI (International Food Policy Research Institute); and Nairobi, Kenya: ILRI (International Livestock Research Institute).

CSA. (2018). Annual Agricultural Sample Survey 2017/18 (2010E.C.) Area and production of major crops

Atilaw, A. (2010). A baseline survey on the Ethiopian seed sector. The African seed trade association. October, 2010. Addis Ababa, Ethiopia.

Endeshaw, H., Shimelis, A., Laike, K., 2008. Participatory Demonstration-cum-Evaluation of Natural.ly 
Ventilated Onion Stores on Small Scale Onion Growing Farmers' Field of the central. Rift Valley., FRG Compiled Research Reports.

Kumelache Alemu, 2015. Production and Dissemination Systems Analyses: The Case of Ethiopia. Food Science and Quality Management www.iiste.org ISSN 2224-6088 (Paper) ISSN 2225-0557 (Online) Vol.35, 2015

MoANR. (2016). Plant varietyrelease, protection and seed quality control directorate: Crop variety register issue No. 18. Addis Ababa, Ethiopia June, 2016.

Zewdie Bishaw, Yonas Sahlu and Belay Simane. 2008. The status of the Ethiopian seed industry. In: Marja HT, B Zewdie, B Abdurahman and S Walter (eds). Farmers, Seeds and Varieties. Wageningen International, the Netherlands

Tripp, R. 1997. New seed and old laws: Regulatory reform and the diversification of nationalseed systems. London, United Kingdom: Intermediate Technology Publications, Ltd. 